\title{
TEKNOLOGI KOMPUTER DAN PROSES KREATIF MUSIK MENUJU REVITALISASI PEMBELAJARAN SENI MUSIK
}

\author{
Tri Wahyu Widodo \\ Dosen tetap Jurusan Musik, FSP ISI Yogyakarta. Email: notasi3@yahoo.co.id
}

\begin{abstract}
The impact of computer technology advancement in current music education as well as musical life in general is undoubtly can not be avoided. Modern music softwares have given a great contribution to musical creativity so that computer technology can help tertiary music education process to be much better.
\end{abstract}

Keywords: Computer technology, music education, musical creativity

\begin{abstract}
Abstrak
Dampak kemajuan teknologi komputer dalam pendidikan musik saat ini dan juga kehidupan musik secara umum tak dapat dihindari. Karena kontribusi yang besar dari berbagai software musik terhadap kreativitas musikal, teknologi komputer dapat membantu proses pendidikan tinggi musik menjadi jauh lebih baik.
\end{abstract}

Kata Kunci: Teknologi komputer, pendidikan musik, kreativitas musikal

\section{Pendahuluan:}

\section{Teknologi Komputer dan Musik}

Teknologi saat ini sudah pasti tidak dapat lepas dari ruang lingkup sendi-sendi kehidupan manusia. Sebuah pola kegiatan yang menggunakan sifat praktis, cepat, tepat sepertinya sudah melekat dalam kehidupan manusia Abad ke-21 ini, sehingga secara tidak langsung dan disadari menjadi sebuah budaya. Ada beberapa pendapat, bahwa manusia tanpa teknologi dapat dikatakan manusia yang tidak berkembang, tidak inovatif atau gagap teknologi.
Dampak ketertinggalan perkembangan teknologi individual atau komunitas tersebut, memunculkan sebuah istilah yang biasa dikenal di pergaulan sosial masyarakat saat ini dengan kata gatek atau gagap teknologi.

Teknologi tidak hanya berpengaruh pada aktivitas sehari-hari umat manusia, tetapi pada bidang dunia seni juga mengalami hal yang sama. Termasuk dalam dunia seni pertunjukan baik dari proses hingga pementasan karya seni, musik berubah bukan hanya karena tradisi 
atau trend oleh suatu faham yang mudah berubah, tetapi musik dipengaruhi oleh perkembangan budaya, komunitas, dan penggunaan alat (tools) keseharian yang berubah (Harjana, 2003:194).

Teknologi muncul diawali dari usaha manusia mencari sesuatu alat untuk membantu mengerjakan dalam kehidupan sehari-hari. Seperti pada jaman Rovolusi Industri, bahwa tenaga mesin menggantikan tenaga manusia, walaupun perkembangan teknologi pada waktu itu masih menggunakan sistem manual mekanik yang digerakkan dengan energi uap, batubara, minyak, dan sebagainya. Seiring dengan hasil kerja teknologi pada saat itu, maka tenologi terus diteliti dan dikembangkan. Kemudian dengan penelitianpenelitian sumber energi untuk kebutuhan daya penggerak mesinmesin yaitu sumber daya alam yang baru seperti energi listrik, maka mesin-mesin pun mengalami perubahan pada sistem kerja, walaupun teknologi yang lama pun saat ini masih banyak digunakan. Sumber energi listrik tidak hanya merubah dalam bentuk fisik suatu mesin tetapi juga sistem kerja operasional mesin tersebut. Perubahan sistem operasional dari suatu mesin manual mekanik menjadi suatu bentuk sistem opersional yang dijalankan dengan sebagian kecil dari tenaga manusia dan alat mesin tersebut berteknologi otomatis.

Sumber daya energi listrik untuk saat ini merupakan penyum- bang utama dalam perkembangan teknologi. Mesin yang menggunakan energi listrik disebut alat elektronik. Tanpa menggunakan daya listrik, peralatan elektronik tidak dapat berfungsi bila tidak terdapat energi listrik. Teknologi dengan energi listrik memberikan perubahan besar dalam peradaban perkembangan teknologi sampai saat ini. Hal ini dapat ditunjukan secara nyata yaitu perubahan bentuk fisik dan sistem operasional dari alat (tools) tersebut. Perkembangan bentuk alat teknologi elektronik yang semakin kecil pun tidak mengurangi kemampuan dari fungsi-fungsi yang dibutuhan oleh manusia. Jadi teknologi elektronik sampai saat ini sudah mengalami berkembang sangat cepat dan memiliki kemampuan yang lebih kompleks dengan mengedepankan suatu kinerja yang efisiensi dan praktis, baik dari segi ruang, tempat, dan waktu.

Seiring dengan perkembangan teknologi otomatis, maka alat elektronik yang menggunakan sumber energi listrik juga berkembang. Salah satu alat elektronik otomatis yang menggunakan energi listrik, baik secara secara mekanisme maupun sistem kerja otomatik untuk menyelesaikan tugas-tugas manusia, dapat dijumpai pada alat elektronik yang memiliki teknologi komputasi atau teknologi komputer. 
Pembahasan:

Teknologi Komputer dan Proses Kreatif Musik Menuju Revitalisasi Pembelajaran Seni Musik

Komputer pada saat ini bukanlah merupakan suatu alat elektronik yang langka lagi. Hal tersebut karena disetiap lingkungan, baik individu maupun kelompok yang meliputi organisasi profesional, dan instansi formal maupun informal, telah menggunakan teknologi komputer ini. Fungsi alat elektronik komputer sampai saat sangat beragam, ada yang digunakan untuk usaha, pendidikan hingga hobby. Salah satu bagian kegiatan yang dipengaruhi oleh teknologi komputer adalah bidang seni yaitu musik. Kemampuan teknologi komputer saat ini memiliki sistem kecerdasan buatan sehingga mampu membantu manusia termasuk dalam bidang seni khususnya musik, seperti mengolah suara atau bunyi-bunyian, menulis notasi hingga difungsikan sebagai alat untuk pertunjukan seni.

Perkembangan musik sekarang telah merambah ke wilayah teknologi yang "smart" atau teknologi yang memiliki kecerdasan. Teknologi komputer merupakan salah satu alat elektronik yang saat ini menjadi trend dalam kegiatan musik, bahkan dengan alat elektronik komputer yang memiliki teknologi cerdas ini mendorong dalam memunculkan suatu aliran seni musik tersendiri dan biasa kita kenal yaitu musik komputer.

Mengenal komputer hingga mengunakan teknologinya untuk musik tidaklah sulit seperti yang kita bayangkan, karena dengan sedikit kemampuan bahasa Inggris dan mencoba-coba (try and error) kita dapat menemukan apa yang akan diinginkan. Kunci pokok dalam menggunakan teknologi komputer untuk musik khususnya pengguna komputer pribadi atau personal computer, seperti desktop, laptop, maupun netbook adalah memiliki jiwa ketekunan dan tidak mudah menyerah.

Proses pendidikan saat ini sudah dituntut untuk menyesuaikan perkembangan teknologi yang ada. Termasuk dalam teknis penyampaian materi mau pun dalam pemutahiran penyusunan bahan ajar. Teknologi alat elektronik saat ini telah berkembang sangat pesat dan memiliki kemampuan yang sangat canggih. Salah satu alat elektronik tersebut adalah komputer. Kemampuan teknologi komputer pada saat ini menggunakan sistem kerja teknologi digital dan hasil kerja elektronik berbentuk data yang terprogram. Data-data hasil dari proses kerja komputer dapat diolah sesuai dengan kebutuhan pengguna komputer. Sebagai contoh, bunyi alat musik direkam secara digital, kemudian diolah ke dalam komputer, maka hasil bunyi alat musik tersebut dapat diolah, baik dari tinggi rendah bunyi, keras kecil volume bunyi dan sebagainya. Begitu pula dalam media grafis, grafis atau gambar yang sudah dicitrakan dalam bentuk data digital, maka dapat diolah sedemikian rupa baik dari segi warna, pencahayaan, dan lain seba- 
gainya sesuai keinginan kebutuhan dari user.

Pengembangan keilmuan bidang seni musik dalam proses belajar mengajar tidaklah berhenti begitu saja. Teknologi komputasi yang telah mem-pengaruhi sendi-sendi proses pendi-dikan, maka perlu dimanfaatkan ke dalam proses belajar mengajar saat ini. Tidak dipungkiri bahwa Program Studi Seni Musik Jurusan Musik Fakultas Seni Pertunjukan ISI Yogyakarta telah memiliki jam terbang yang tinggi dalam proses belajar mengajar seni musik dan sangat perlu merevitalisasi proses pembelajaran secara manual menuju pembelajaran menggunakan teknologi komputer. Walaupun sampai saat ini proses belajar mengajar seni musik yang berjalan di Jurusan Musik menjadi rujukan dalam membuat kurikulum di beberapa perguruan tinggi di Indonesia. Kurikulum Jurusan musik juga selalu dikembangkan dan disesuaikan dengan perkembangan seni yang ada sesuai tantangan jaman.

Pada dasarnya, tujuan dari pembelajaran musik pada semua jenjang pendidikan sama. Pembelajaran musik mempunyai tujuan untuk: 1) memupuk rasa seni pada tingkat tertentu dalam diri melalui perkembangan kesadaran musik, tanggapan terhadap musik, kemampuan mengungkapkan dirimelalui musik, sehingga memungkinkan mengembangkan kepekaan terhadap dunia sekelilingnya; 2) mengembangkan kemampuan menilai musik melalui intelektual dan artistik sesuai dengan budaya bangsanya; dan 3) dapat dijadikan bekal untuk melanjutkan studi ke pendidikan musik yang lebih tinggi (Jamalus, 1998 :91).

Proses belajar mengajar musik harus memperoleh pengalaman bermusik, yaitu melalui kegiatan mendengarkan, bermain musik, bernyanyi, membaca musik, dan bergerak mengikuti musik, sehingga peserta didik dapat memperoleh gambaran yang utuh dan menyeluruh. Melalui teknologi komputer dapat membantu dalam memberikan suatu pemahaman terhadap unsur-unsur atau elemenelemen musik seperti irama, melodi, harmoni, bentuk dan gaya musik, serta ekspresi sebagai bagian dari pengalaman bermusik.

Dengan demikian, proses pembe-lajaran musik di Program Studi Seni Musik Jurusan Musik Fakultas Seni Pertunjukan ISI Yogyakarta sangat perlu untuk merevitalisasi berbagai metode pembelajaran musik yang berbasis manual ditunjang pembelajaran musik dengan berbasis teknologi. Teknlogi komputer memberikan bantuan sebagai media untuk mengoptimalkan proses belajar musik sebagai sarana pembentukan pribadi, maka pendekatan pembelajaran yang digunakan sebaiknya adalah pembelajaran musik berbasis kreativitas. Dengan teknologi komputer pembelajaran musik berbasis kreativitas tidak hanya menekankan pelajaran musik dari segi teori, tetapi juga praktik, serta sebanyak mungkin 
melibatkan kreativitas dalam pembelajaran musik.

Pembelajaran musik berbasis kreativitas memberikan peluang dan wadah bagi peserta didik untuk berperan dengan imajinasi dan kreativitasdalam proses belajar mengajar musik. Pembelajaran musik berbasis kreativitas akan menanamkan pemahaman terhadap unsur-unsur musik seperti irama, melodi, harmoni, bentuk, dan style serta ekspresi musik dengan me-masukkan berbagai unsur kreativitas yang sudah dirancang oleh pengajar dalam kegiatan proses belajar mengajarnya. Ketercapaian sasaran dalam pembelajaran merupakan sebagian awal dari upaya meningkatkan kreativitas dan meningkatkan pemahaman pelajaran musik.

Minat untuk lebih serius mengikuti pelajaran musik juga dapat dipe-ngaruhi oleh faktor dari luar, seperti metode pengajaran yang disampaikan. Metode pembelajaran musik yang menarik, akan menciptakan minat untuk mengikuti pelajaran yang disampaikan. Istilah pembelajaran sebenarnya diambildari bahasa Inggris, yaitu Instruction yang berarti pengajaran. Gagne dan Briggs (Mukminan, 1998: 5) mendefinisikan pembelajaran sebagai suatu rangkaian kejadian (event) yang mempengaruhi pembelajar, sehingga proses belajar dapat berlangsung dengan mudah. Sementara itu, Syah (2004: 32) menyatakan arti pembelajaran sama dengan pengajaran yang berasal dari kata "ajar" artinya petunjukyang diberikan kepada orang supaya diketahui (diturut). Berdasarkan hal itu, arti pengajaran merupakan memberikan suatu pengarahan agar melakukan sesuatu; dapat juga berarti mengajar agar melakukan sesuatu, dan memberi informasi.

Penguasaan akan teknologi komputer memberikan dukungan peningkatan kreativitas seni dan merevitalisasi pemahaman dalam proses belajar mengajar seni musik di Jurusan Musik Fakultas Seni Pertunjukan ISI Yogyakarta. Dengan demikian teknologi komputasi yang berkembang saat ini sangat mendukung kurikulum seni musik yang sedang berjalan dan berbasis kompetensi. Berkaitan dengan teknis menggunakan teknologi komputer tidak sesulit yang dibayangkan, hanya saja memerlukan suatu ketelitian, ketekunan, dan moto pantang menyerah. Kesalahan pada proses menjalankan teknologi komputer akan memberikan pengalaman dan pelajaran yang sangat penting.

Perangkat lunak atau software untuk mendukung kreativitas seni dalam merevitalisasi seni musik dapat dilakukan dengan cara membuat sendiri ataupun dengan membeli perangkat lunak yang sudah jadi. Perangkat lunak atau software yang mendukung kreativitas dalam proses pembelajaran musik dapat kelompokkan beberapa bagian. Seperti software untuk menulis notasi, antara lain Sibelius, Finale, dsan Encore. Program aplkiasi ini dapat digunakan untuk membuat karya musik, belajar 
membuat komposisi, aransemen dan masih banyak alagi fungsinya. Kemudian perangkat lunak untuk mengolah bunyi hingga menjadi sebuah karya utuh dan menjadi seni industri kreatif, yaitu Sonar, Pro Tools, Cakewalk, Nuendo dan masih banyak lagi. Adapun program aplikasi musik interaktif, progam ini dibuat secara khusus untuk meperesentasikan mata pelajaran seperti, teori musik, solfegio, sejarah musik, sejarah alat musik dan sebagainya. Program apaliaksi musik interaktif ini seperti; Music Theory, Essentials of Music Theory Version 1.0 (c) 2000 dari Alfred Publishing, Music for Musicians \& Singers, dan Auralia Ver. 4, merupakan program aplikasi untuk melatih atau proses pembelajaran secara kreatif dalam melatih pendengaran atau solfegio.

\section{Penutup}

Demikian sekilas uraian bahwa teknologi komputer sangat membantu dalam proses pembelajaran seni khususnya seni musik. Komputer juga memberikan peluang besar dalam proses kreatif seni musik yang bertujuan merevitalisasi pembelajaran musik di Jurusan Musik Fakultas Seni Pertunjukan ISI Yogyakarta.

\section{Referensi}

Jamalus. 1988. Pengajaran Musik

\footnotetext{
melaluiPengalaman Musik.

Jakarta: Depdikbud
}

Mukminan, dkk. 1998. Belajar dan Pembelajaran. Yogyakarta: IKIP Yogyakarta.

Munandar, U. 1999. Kreativitas dan Keberbakatan: Strategi mewujudkan Potensi Kreatif dan Bakat. Jakarta: PT. Gramedia Utama.

Harjana, Suka. 2003. Corat Coret Musik Kontemporer Dahulu dan Masa Kini. Jakarta: MSPI

Syah, M. 2004. Psikologi Pendidikan dengan Pendekatan Baru. Bandung: Remaja Rosda Karya. 